Check for updates

Cite this: RSC Adv., 2019, 9, 20687

Received 2nd May 2019

Accepted 4th June 2019

DOI: 10.1039/c9ra03271a

rsc.li/rsc-advances

\section{Effects of rare-earth oxides on the microstructure and properties of Fe-based friction materials synthesized by in situ carbothermic reaction from vanadium-bearing titanomagnetite concentrates}

\begin{abstract}
Dajun Zhai, ${ }^{\text {ab }}$ Yue Shui, (DD a Keqin Feng (D) *a and Yanyan Zhang ${ }^{\text {a }}$
In this work, we prepared an iron-based frictional material from vanadium-bearing titanomagnetite concentrates by in situ carbothermic reaction with improved tribological properties. Effects of different amounts of rare-earth oxides on the microstructure and properties of the Fe-based friction materials were investigated. The microstructure of the Fe-based friction material consisted of an Fe matrix, hard particles (mainly $\mathrm{TiC}$ ) and a lubricating phase (graphite). The moderate addition of rare-earth oxides improved the microstructure and properties of the Fe-based friction material significantly. Particularly, the friction coefficient decreased from 0.61 to $0.48-0.56$ and the wear rate reduced from $7.8 \times 10^{-7}$ $\mathrm{cm}^{3} \mathrm{~J}^{-1}$ to $2.6 \times 10^{-7} \sim 4.9 \times 10^{-7} \mathrm{~cm}^{3} \mathrm{~J}^{-1}$. Addition of $\mathrm{La}_{2} \mathrm{O}_{3}$ ( $\leq 0.2 \mathrm{wt} \%$ ) or $\mathrm{CeO}_{2}(\leq 0.4$ wt\%) contributed to sintering densification and improved the relative density, hardness and wear resistance. The dominant wear mechanism changes from severe abrasive wear and oxidative wear to mild oxidative wear. However, when rare-earth oxide addition was increased further, the microstructure, relative density, hardness, and wear performance of the Fe-based friction materials deteriorated. Consequently, the optimal additions of $\mathrm{La}_{2} \mathrm{O}_{3}$ and $\mathrm{CeO}_{2}$ were $0.2 \mathrm{wt} \%$ and $0.4 \mathrm{wt} \%$, respectively.
\end{abstract}

\section{Introduction}

Friction composites are important parts of brakes, clutches and friction gearings for all types of vehicles. They directly relate to the reliability and stability of the operation systems. Therefore, they have to show stable friction coefficients and low wear rates over wide ranges of operating conditions, as well as stability at higher temperatures. In order to improve the tribological properties of materials, researchers focus on the addition of alloying elements, reinforced phases and lubricating components. The performance of friction materials is mainly controlled by their composition and microstructure. As for metal-matrix friction materials, the addition of suitable alloying elements contributes to the effective improvement of the friction properties. $\mathrm{Xu}$ et al. have found that the appropriate addition of Ni element strengthens the matrix of copper-based friction material and decreases the wear rate remarkably. ${ }^{1}$ Yang has shown that the addition of $\mathrm{Al}$ and $\mathrm{Zr}$ contributes to the improved tribological performance of $\mathrm{Fe}-18 \mathrm{Cu}$-based friction material. ${ }^{2}$ A suitable amount of reinforced phases and lubricating components also ameliorates the tribological

${ }^{a}$ School of Mechanical Engineering, Sichuan University, Chengdu 610065, China. E-mail: kqfeng@scu.edu.cn

${ }^{b}$ Department of Materials Engineering, Sichuan Engineering Technical College, Deyang 618000, China performance of friction material. For instance, Ma added natural fiber (pine needle fiber) into friction composite as reinforced phase and prepared a friction material with stable friction coefficient and low wear rate. ${ }^{3}$ Marie et al. concerned the influence of titanium dioxide on the characteristics of $\mathrm{Fe}-10 \%$ $\mathrm{Cu}-7 \%$ graphite-12\% Ni materials and found that the presence of titanium dioxide has a beneficial influence in a certain content range on the tribological characteristics. ${ }^{4}$ Peng et al. prepared the improved tribological properties of $\mathrm{Cu}-\mathrm{Fe}$-based friction materials by adding $\mathrm{FeS}$ and $\mathrm{MoS}_{2} \cdot{ }^{5}$ In addition, the surface treatment can also be used to improve the friction and wear properties of materials, such as the improvement of surface texture. ${ }^{6}$

Friction materials prepared by powder metallurgy techniques have been used extensively in aircraft, tanks, high-speed trains, brakes, and clutches. Traditional Fe-based powder metallurgy friction materials are prepared with iron powders of high purity, solid lubricants such as $\mathrm{MoS}_{2}$, graphite etc. and abrasives such as $\mathrm{SiO}_{2}$, TiC, etc. ${ }^{-9}$ However, this traditional mechanical mixing method still has disadvantages. For one thing, the wettability between the added components and Fe matrix is poor. It is easy for reinforcement to spall off from matrix, which increases the wear rate of material seriously. ${ }^{\mathbf{1 0}}$ For another thing, the preparation of various pure substance powders is often costly and time-consuming. ${ }^{11}$ In order to overcome the shortcomings of traditional mechanical mixing 
method, in situ synthesis technology has attracted extensive attention in the preparation of powder metallurgy friction materials in recent years.

As an abundant, important, and complex ore, vanadiumbearing titanomagnetite concentrates consist of large amounts of ferrous oxides as well as $\mathrm{TiO}_{2}, \mathrm{~V}_{2} \mathrm{O}_{5}, \mathrm{SiO}_{2}, \mathrm{Al}_{2} \mathrm{O}_{3}$, $\mathrm{CaO}$, and $\mathrm{MgO}$. By carbon thermal reaction, the ferrous oxides are converted to metal iron, which acts as matrix of Fe-based friction materials. $\mathrm{TiO}_{2}$ and $\mathrm{V}_{2} \mathrm{O}_{5}$ react with $\mathrm{C}$ to form TiC and $\mathrm{VC}$, which can be used as hard particles of Fe-based friction materials. The remaining $\mathrm{SiO}_{2}, \mathrm{Al}_{2} \mathrm{O}_{3}, \mathrm{CaO}$, and $\mathrm{MgO}$ also serve as abrasives. The compositions of vanadium-bearing titanomagnetite concentrates after carbothermal reactions meet the compositional characteristics of iron-based friction material. Therefore, it is possible to find an alternative method to prepare an iron-based friction material by means of selective in situ carbothermic reactions of the vanadium-bearing titanomagnetite concentrates. The preparation of Fe-based friction materials synthesized by in situ carbothermic reaction from vanadiumbearing titanomagnetite concentrates not only overcomes shortcomings of traditional mechanical mixing method, but also make good use of various elements in the vanadiumbearing titanomagnetite concentrates simultaneously.

Some Fe-matrix composites can be prepared directly from natural minerals by in situ synthesis technology, which has attracted the interest of researchers because of the potential for process simplification and cost reduction. Welham and Willis prepared titanium nitride (TiN)/TiC-Fe composites from ilmenite concentrate by in situ reaction. ${ }^{12}$ Razieh Khoshhal used cheap ilmenite as raw material to synthesize $\mathrm{Fe}-\mathrm{TiC} / \mathrm{Al}_{2} \mathrm{O}_{3}$ composite material by in situ reaction. ${ }^{\mathbf{1 3}}$ However, until recently, few reports have been concerned with preparing materials from vanadium-bearing titanomagnetite by in situ synthesis technology.

Our research group previously reported the preparation and properties of an Fe-based friction material by in situ reaction and sintering from vanadium-bearing titanomagnetite concentrates under in vacuum. ${ }^{\mathbf{1 4 - 1 6}}$ The prepared Fe-based friction material meets the basic requirements of JBT 30631996. In order to make further improvements about the properties of the Fe-based friction material, an addition of alloying elements is considered in this study.

In the early 1950s, people began to study the application of rare-earth elements in iron and steel. After long-term exploration and research, it was found that rare-earth elements plays a role of solid solution strengthening and grain refinement in steel and cast iron. Moreover, rare-earth elements combines with other strengthening phases to form new strengthening items and rare earth element reduce the harmful effects of $S$ and $\mathrm{P}$ impurities in nodular cast iron. Thus, the impact toughness of steel is improved, the brittle transition temperature of steel is reduced, the anisotropy of steel is improved, and the quality of steel is remarkably improved. ${ }^{17-21}$ In view of the good role of rare earth in iron and steel, researchers began to study the role of rare earth in iron-based powder metallurgical materials.
The chemical properties of rare-earth elements are very active, so it is difficult to add them directly to the materials. Our research group have studied the effect of the addition form of rare-earth on the iron-based friction material. Li Ying et al. have researched the effect of rare-earth master alloy (FeSiMg9RE9) on the iron-based friction material. ${ }^{22}$ The results show that rareearth can promote the sintering densification process and improve tribological properties in this system obviously. Compared with rare earth master alloys, rare-earth oxide is of lower price. In order to make further improvements to the material's performance and service life, this paper refers to the beneficial role of rare-earth oxides in iron-based materials and focuses on the effects of $\mathrm{La}_{2} \mathrm{O}_{3}$ and $\mathrm{CeO}_{2}$ on the microstructure and properties of Fe-based friction material prepared by in situ carbothermic reaction from vanadium-bearing titanomagnetite concentrates. The findings show that it is promising to find an optimal addition of rare-earth oxides to greatly improve the tribological properties of the material.

\section{Materials procedure}

\subsection{Materials}

The vanadium-bearing titanomagnetite concentrate powder, Fe powder $(\leq 44 \mu \mathrm{m}$, with $99.5 \%$ purity), rare-earth oxide powder $(\leq 74 \mu \mathrm{m}$, with $99.0 \%$ purity) and graphite $(44 \mu \mathrm{m}$, with $99.8 \%$ purity) which acts as reductant and lubricant are the main materials for the preparation of iron-based friction material. Fe powder, rare-earth oxide powder and graphite powder are supplied by Nangong Chunxu Metal Material Co., Ltd.

Vanadium-bearing titanomagnetite was supplied by Panzhihua Iron and Steel Company (China), and its chemical composition and XRD analysis are presented in Table 1 and Fig. 1. It can be seen that vanadium-bearing titanomagnetite concentrates is mainly consisted of $\mathrm{Fe}_{3} \mathrm{O}_{4}$ and $\mathrm{FeTiO}_{3}$, as well as $\mathrm{Al}_{2} \mathrm{O}_{3}, \mathrm{SiO}_{2}, \mathrm{MgO}$ and $\mathrm{CaO}$. The processes for preparing $\mathrm{Fe}-$ based friction material from vanadium-bearing titanomagnetite concentrates is consisted of carbothermic reaction of vanadium-bearing titanomagnetite concentrates and a final sintering process of green samples.

In the carbothermic reaction process, first, the vanadiumbearing titanomagnetite concentrate and reluctant graphite (at a ratio of $100: 20.3 \mathrm{wt} \%$ ) were mixed in the mill at $400 \mathrm{rpm}$ for 4 hours. The mixture was then heated in vacuum furnace at $1300{ }^{\circ} \mathrm{C}$ for 3 hours at a pressure of $5 \mathrm{~Pa}$ and the pre-reduced powder was obtained. The chemical compositions and XRD analysis of the pre-reduced powder are presented in Table 2 and Fig. 2. From Fig. 2 and Table 2, it can observed that ferrous oxide has been reduced into metal iron,

Table 1 The chemical compositions of vanadium and titanium iron concentrate (wt\%)

\begin{tabular}{llllllllll}
\hline $\mathrm{Fe}_{2} \mathrm{O}_{3}$ & $\mathrm{FeO}$ & $\mathrm{TiO}_{2}$ & $\mathrm{~V}_{2} \mathrm{O}_{5}$ & $\mathrm{Al}_{2} \mathrm{O}_{3}$ & $\mathrm{SiO}_{2}$ & $\mathrm{MgO}$ & $\mathrm{CaO}$ & $\mathrm{S}$ & \multicolumn{2}{l}{$\mathrm{P}$} \\
\hline 42.6 & 30.02 & 12.65 & 0.56 & 4.085 & 3.89 & 3.91 & 1.57 & 0.677 & 0.038
\end{tabular}




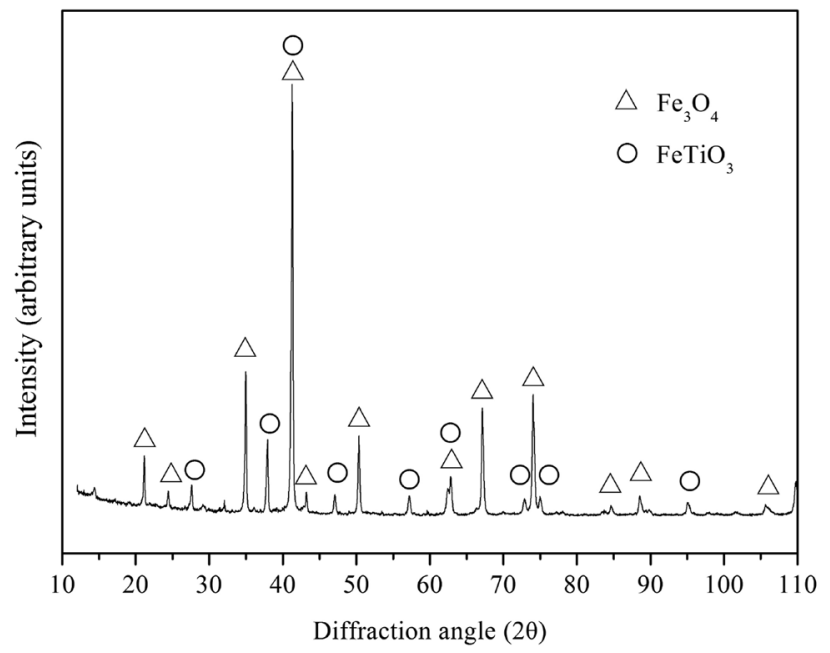

Fig. 1 XRD analysis of vanadium-bearing titanomagnetite concentrates.

titanium oxide and vanadium oxide are converted into TiC and VC. According to the experimental mass loss, it can be calculated that the percentage of ferrous oxides reduced to metal iron is about $96 \%$, the percentage of $\mathrm{FeTiO}_{3}$ converted into TiC is about $75 \%$ and the percentage of $\mathrm{V}_{2} \mathrm{O}_{5}$ converted into $\mathrm{VC}$ is about $94 \%$.

In the final sintering process, first, the pre-reduced powder (78.72 wt\%), supplementary Fe powder (15.28 wt\%), and lubricant graphite powder ( $6 \mathrm{wt} \%)$ were mixed to form the basic ingredient, according to according to the composition requirement of typical iron-based friction material (JB/ T3063-2011). Next, the basic ingredient was admixed with different addition (0-0.6 wt\%) of $\mathrm{La}_{2} \mathrm{O}_{3}$ or $\mathrm{CeO}_{2}$. Then the powders were mixed into a grinding mill for 30 minutes. Later, the mixed powders were placed in a steel mold and pressed under $400 \mathrm{MPa}$ by a hydraulic oil press, and the green samples were sintered at a temperature of $1050^{\circ} \mathrm{C}$ for 3 hours in a vacuum furnace.

\subsection{Analysis}

The microstructure of the sintered samples was observed with scanning electron microscopy (SEM, Phenom ProX). The phase composition was analysed by X-ray diffraction (XRD) using a AL-2700B X-ray diffraction apparatus with Co Ka radiation. The scanning voltage was $20 \mathrm{kV}$, the current was 50 $\mathrm{mA}$, the scanning range was $10-110^{\circ}$ and the scanning rate was $5^{\circ} \mathrm{min}^{-1}$. According to GB/T 10421-2002, the density was measured by the Archimedes drainage method and Brinell

Table 2 Chemical compositions of pre-reduction mineral powder (wt\%)

\begin{tabular}{lllllllll}
\hline $\mathrm{MFe}$ & $\mathrm{FeO}$ & $\mathrm{TiC}$ & $\mathrm{VC}$ & $\mathrm{Al}_{2} \mathrm{O}_{3}$ & $\mathrm{SiO}_{2}$ & $\mathrm{MgO}$ & $\mathrm{CaO}$ & Others \\
\hline 74.50 & 1.07 & 10.69 & 0.53 & 5.90 & 4.71 & 1.25 & 1.23 & 0.13
\end{tabular}

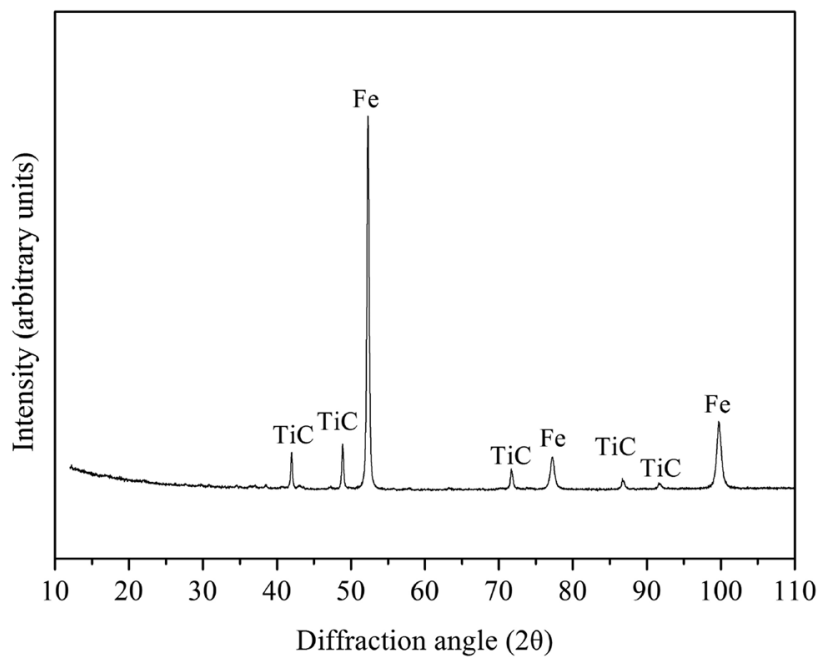

Fig. 2 XRD analysis of the pre-reduced powders.

hardness of sintered samples was measured with an electronic tester (HBE-3000A). In the hardness test, the load was $612.5 \mathrm{~N}$, the holding time was $15 \mathrm{~s}$, and the indenter was cemented carbide ball with $2.5 \mathrm{~mm}$.

The chemical states of some typical elements on the worn surfaces were determined using a PHI-5702 X-ray photoelectron spectroscope (XPS) at a pass energy of $29.4 \mathrm{eV}$ and a resolution of $70.2 \mathrm{eV}$, using $\mathrm{Al} \mathrm{K} \alpha$ radiation as the excitation source and the binding energy of adventitious carbon (C1s: $284.8 \mathrm{eV})$ as the reference.

\subsection{Friction and wear test}

A schematic illustration of the wear test process is presented in Fig. 3. Specimens having dimension of $\varphi 13 \times 11 \mathrm{~mm}$ were evaluated on block-on-ring tester (M-2000, Zhang Jiakou Kehua Testing Machine Manufacturing Co., Ltd.). Samples

\section{$\mathrm{Fn}$}

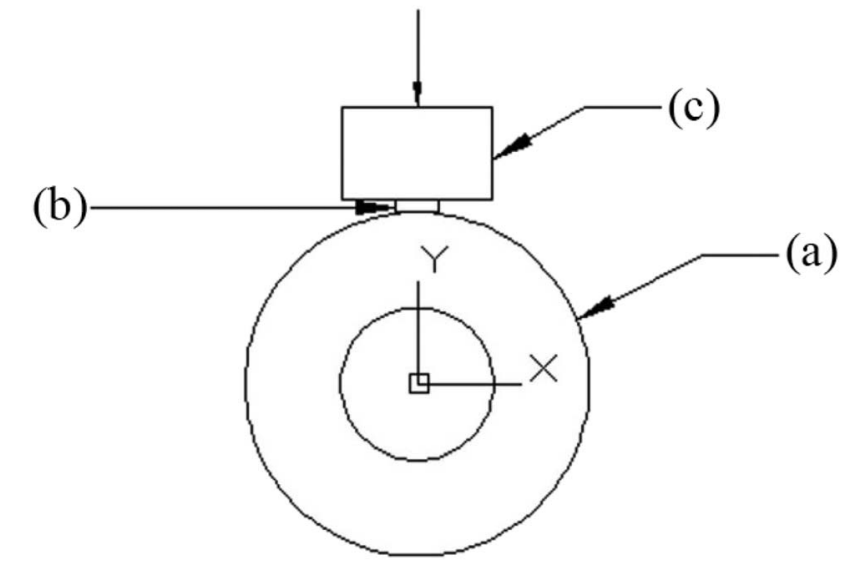

Fig. 3 Diagram of block-on ring tester (a) grinding wheel, (b) specimen, and (c) load. 

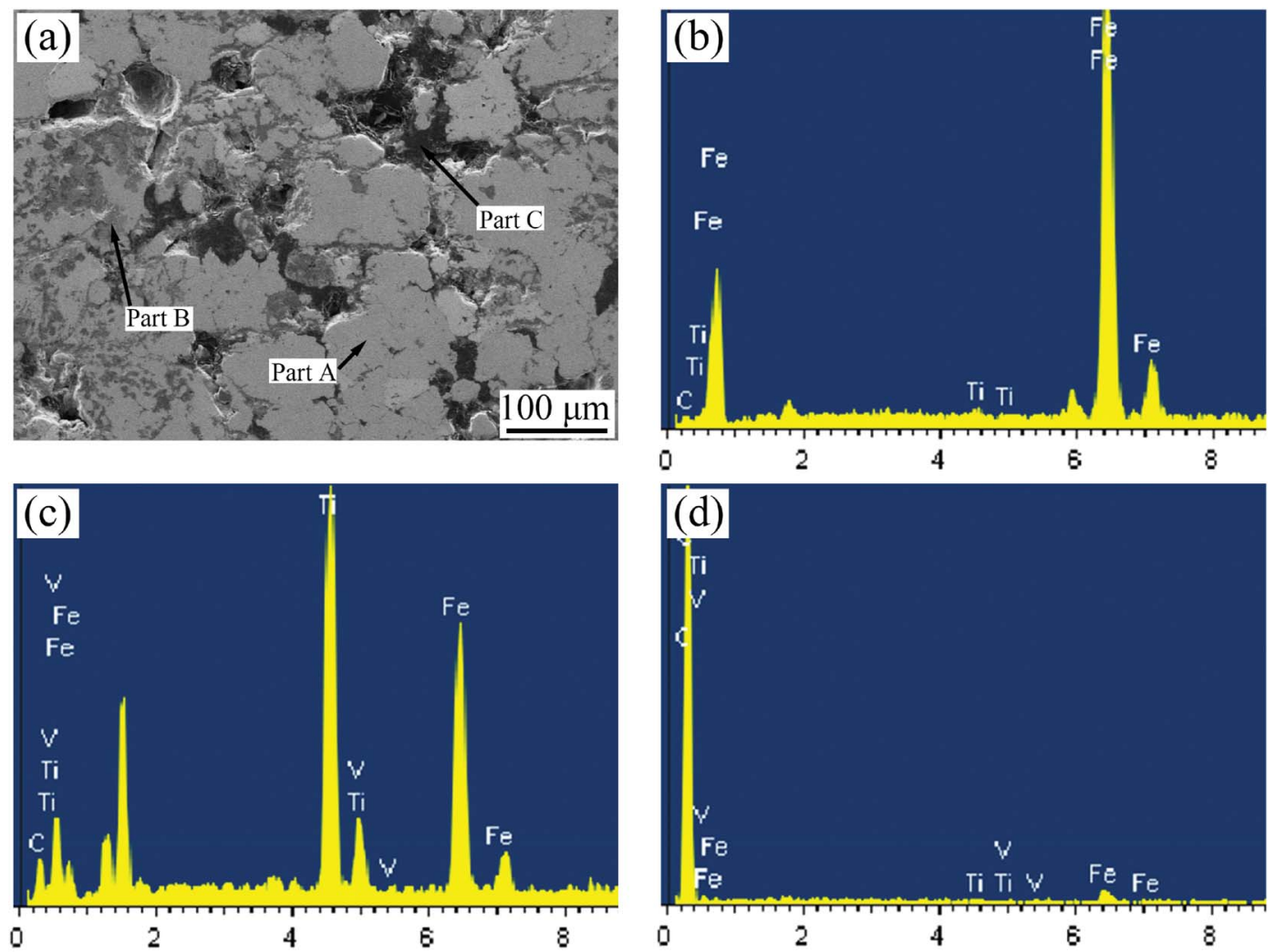

Fig. 4 Microstructure of sintered sample (a) and EDS analysis of area A (b), B (c) and D (d).

were weighted before testing. The wheel was rotated at $210 \mathrm{rpm}$ and the samples were pressed against the wheel with a load of $200 \mathrm{~N}$. After the test, the weight loss was measured with a precision electron balance (Model BSA124S, Beijing Sartorius Co., Ltd. China) with an error of $\pm 0.1 \mathrm{mg}$ for mass loss determination. Weight loss was converted into volume loss. The coefficient of friction was obtained directly by the block-on-ring tester. We repeated the wear test three times for each sintered sample.

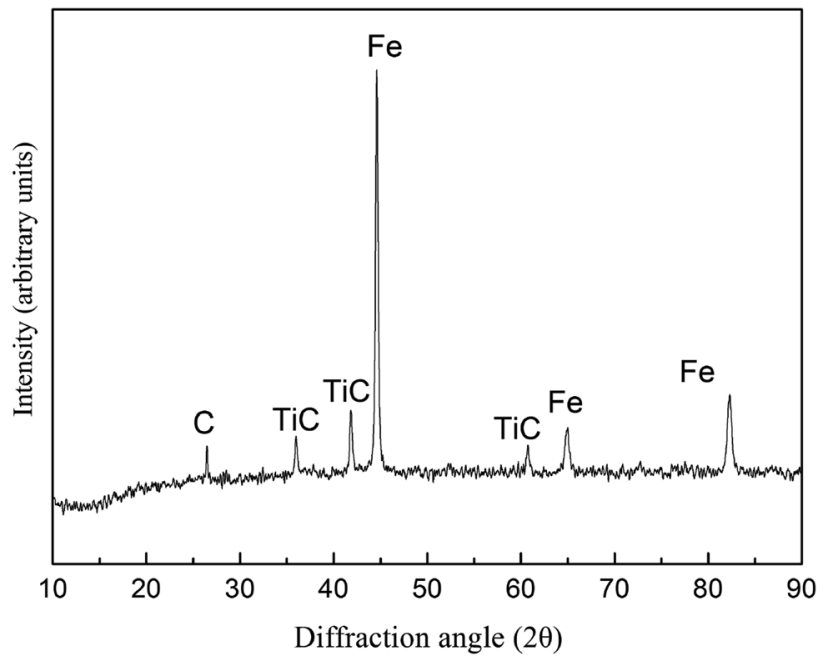

Fig. 5 XRD pattern of the sintered sample without rare-earth oxide.

\section{Results and discussion}

\subsection{Microstructure and phase composition of Fe-based friction materials}

Fig. 4 shows the microstructure of Fe-based friction materials synthesized in situ from vanadium-bearing titanomagnetite concentrates. As seen in Fig. 4(a), there are three areas with different shades of gray can be seen in the sample: area A is pale-gray, area B is gray, and area D is black. The EDS analysis results show that area $\mathrm{A}$ is dominated by $\mathrm{Fe}$ and $\mathrm{C}$ atoms, area $\mathrm{B}$ by Ti and $\mathrm{C}$ atoms, and area D by $\mathrm{C}$ atoms, as seen in Fig. 4(b)(d) and Table 2. The XRD pattern reveals that the sintered samples mainly contain Fe, TiC and C phases, as seen in Fig. 5. Thus, the titanium oxides are transformed into TiC in the carbon-thermal reduction process, which plays a role of hard particle phase. The graphite powder (area D) acting as a lubricant remains in the gap (Table 3).

\subsection{Effect of rare-earth oxides on the milling process}

Morphologies of reduced powders with $\mathrm{La}_{2} \mathrm{O}_{3}$ and $\mathrm{CeO}_{2}$ additives are shown in Fig. 6 . The powder particle size is reduced obviously when $0.2 \mathrm{wt} \% \mathrm{La}_{2} \mathrm{O}_{3}$ or $0.4 \mathrm{wt} \% \mathrm{CeO}_{2}$ is added. Besides, the size of powder particle $0.4 \mathrm{wt} \% \mathrm{CeO}_{2}$ is smaller than that with $0.2 \mathrm{wt} \% \mathrm{La}_{2} \mathrm{O}_{3}$. In the powder metallurgy materials, rare-earth can not be directly added into as pure metal powder because of its active chemical properties. Thus, rareearth master alloys and rare-earth oxides are common forms 
Table 3 EDS analysis results of area A, B, and C (atom fraction \%)

\begin{tabular}{lrrrr}
\hline Part & Fe & \multicolumn{1}{c}{ C } & \multicolumn{1}{c}{ Ti } & V \\
\hline A & 94.65 & 4.78 & 0.57 & - \\
B & 47.49 & 12.55 & 37.32 & 2.64 \\
C & 4.54 & 94.70 & 0.46 & 0.30 \\
\hline
\end{tabular}

of rare earth additions. Different from adding rare earth master alloys, the chemical properties of rare earth oxides are very stable, and it is difficult to decompose into active rare earth atoms at ordinary sintering temperature. Therefore, rare earth oxides are added into the milling system as hard particles. In the process of mechanical milling, rare earth oxides play a role of cutting and crushing, which accelerates the deformation of powder and the exfoliation of surface oxides. ${ }^{17}$
Table 4 shows the crystalline structure and lattice constants of $\mathrm{La}_{2} \mathrm{O}_{3}$ and $\mathrm{CeO}_{2} \cdot{ }^{23,24}$ For crystalline structure, the calculation formula of crystal cell volume is as follows:

$$
V=3 a^{2} \times c \times \sin 60^{\circ}
$$

For crystalline structure, the calculation formula of crystal cell volume is as follows:

$$
V=a^{3}
$$

By substituting the lattice constants of $\mathrm{La}_{2} \mathrm{O}_{3}$ and $\mathrm{CeO}_{2}$ into formula (1) and (2), it can be calculated that the crystal cell volume of $\mathrm{La}_{2} \mathrm{O}_{3}$ and $\mathrm{CeO}_{2}$ are respectively $0.247 \mathrm{~nm}^{3}$ and 0.157 $\mathrm{nm}^{3}$.

In the milling process, the fining effect of iron powder is sensitive to the size of rare-earth oxide. It can be noted that
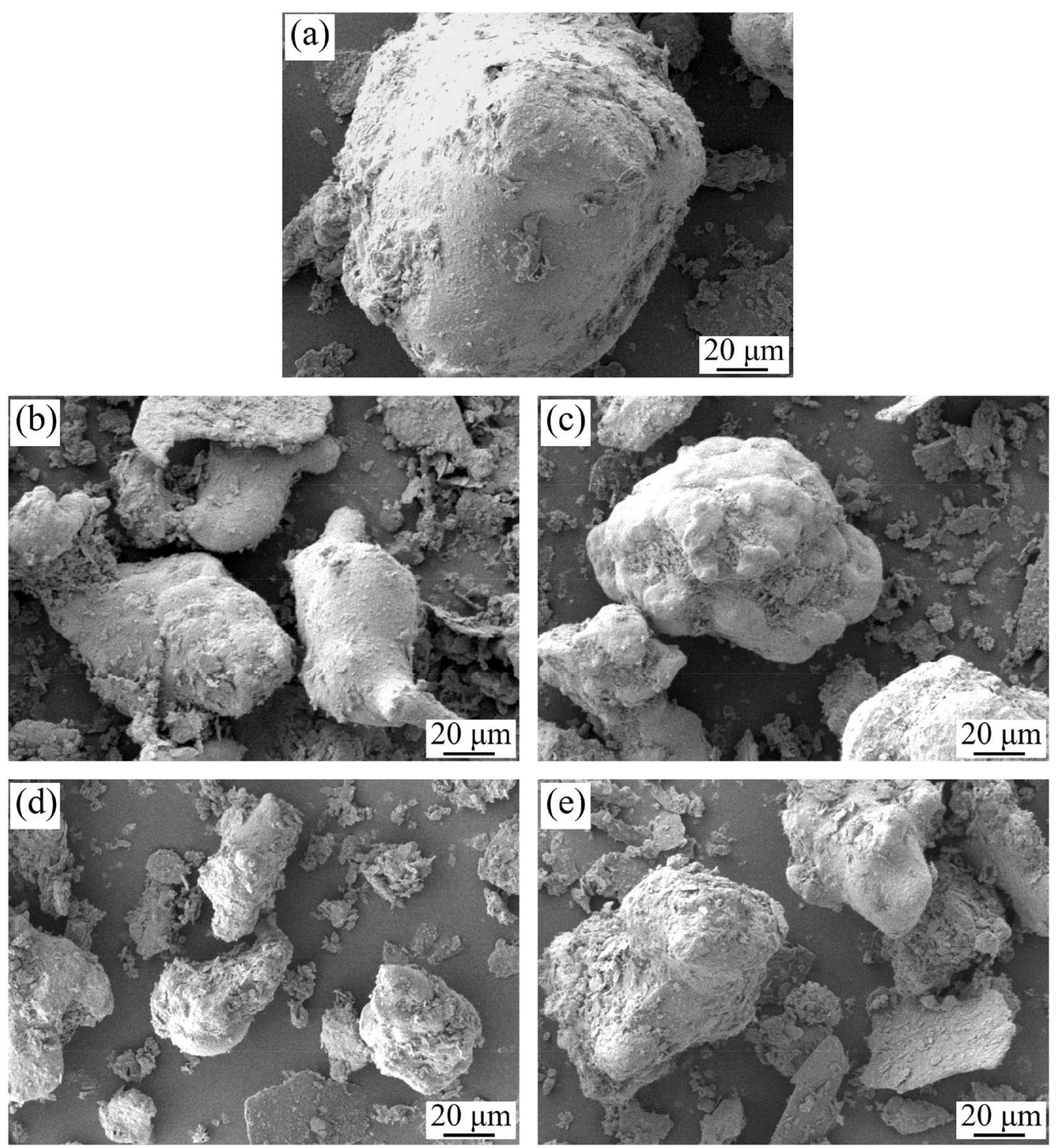

Fig. 6 SEM micrographs of powders (a) without and with (b) 0.2 wt $\% \mathrm{La}_{2} \mathrm{O}_{3}$, (c) 0.4 wt $\% \mathrm{La}_{2} \mathrm{O}_{3}$, (d) 0.4 wt\% $\mathrm{CeO}_{2}$ and (e) 0.6 wt\% $\mathrm{CeO}$. 
Table 4 The crystalline structure and lattice constants of $\mathrm{La}_{2} \mathrm{O}_{3}$ and $\mathrm{CeO}_{2}$

\begin{tabular}{lll}
\hline & $\mathrm{La}_{2} \mathrm{O}_{3}$ & $\mathrm{CeO}_{2}$ \\
\hline Crystalline structure & Hexagonal crystalline structure & Cubic crystalline structure \\
Lattice constant of $a$ & $0.3938 \mathrm{~nm}$ & $0.5400 \mathrm{~nm}$ \\
Lattice constant of $c$ & $0.613 \mathrm{~nm}$ & - \\
\hline
\end{tabular}

$0.4 \mathrm{wt} \% \mathrm{CeO}_{2}$ has better effect on the fining particle than that of $0.2 \mathrm{wt} \% \mathrm{La}_{2} \mathrm{O}_{3}$. This may be due to the fact that the small size of $\mathrm{CeO}_{2}$ has more collision points with iron powder and thus it is easier to crush and refine iron powder particles. ${ }^{17}$

\subsection{Effect of rare-earth oxides on the microstructure of Fe- based friction materials}

Fig. 7 shows the microstructure of the sintered specimens produced with $\mathrm{La}_{2} \mathrm{O}_{3}$ and $\mathrm{CeO}_{2}$ additives. A small amount of $\mathrm{La}_{2} \mathrm{O}_{3}(0.2 \mathrm{wt} \%)$ promotes the formation of a sintering neck between iron powder particles and reduces the porosity of sintered samples, as seen in Fig. 7(a). Further addition of $\mathrm{La}_{2} \mathrm{O}_{3}$ does result in further improvement of the density or phase distribution of sintered samples, as seen in Fig. 7(c) and (e). Fig. 7(c) shows that the highest relative density of sintered samples and the most uniform distribution of TiC occur when the amount of $\mathrm{CeO}_{2}$ additive was $0.4 \mathrm{wt} \%$.

In the mechanical milling process, the rare-earth oxides participate in cutting and crushing, which accelerates powder
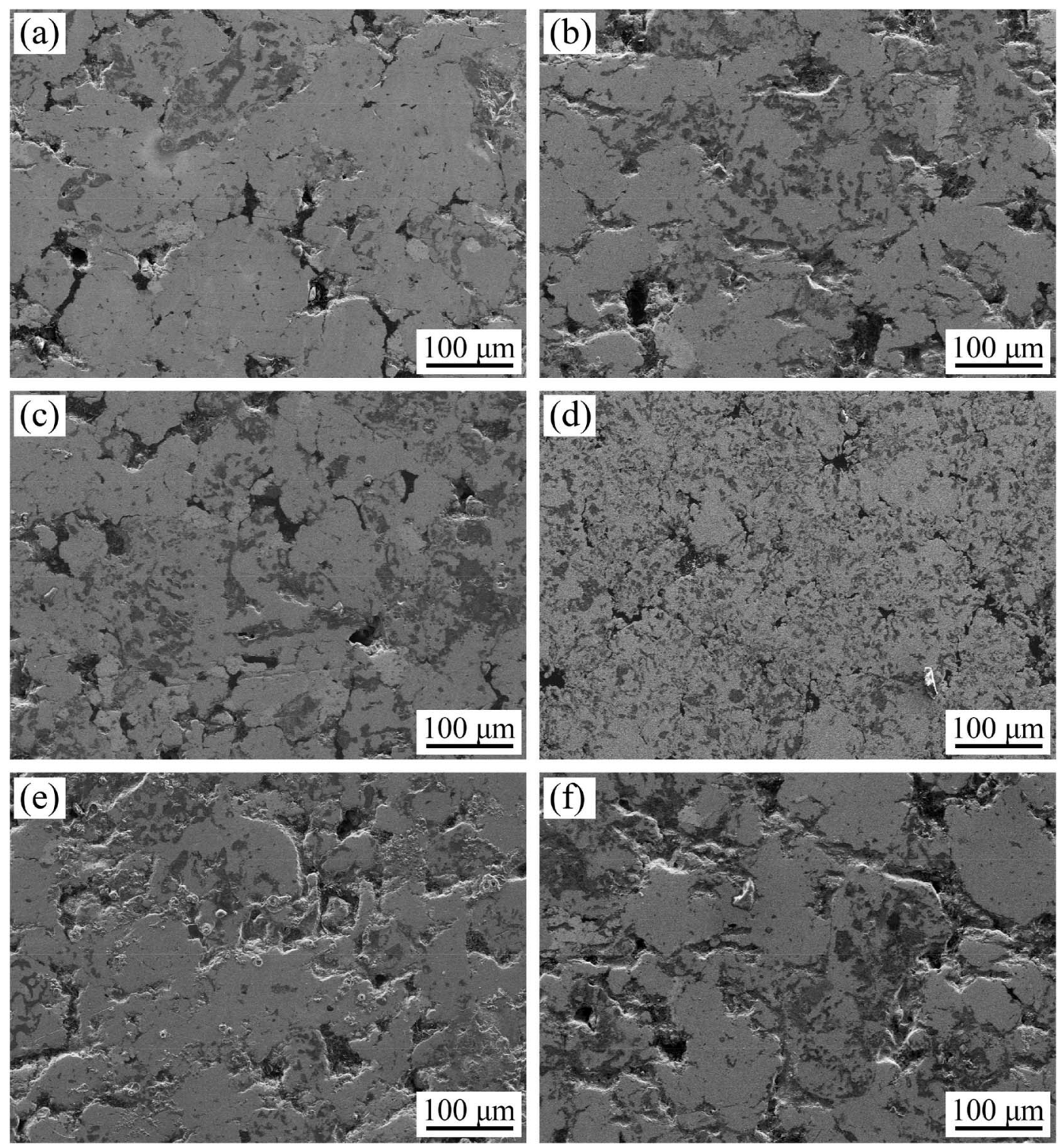

Fig. 7 Microstructure of the sintered specimens with (a) $0.2 w t \% \mathrm{La}_{2} \mathrm{O}_{3}$, (b) $0.2 \mathrm{wt} \% \mathrm{CeO}_{2}$, (c) $0.4 \mathrm{wt} \% \mathrm{La}_{2} \mathrm{O}_{3}$, (d) $0.4 \mathrm{wt} \% \mathrm{CeO}_{2}$, (e) $0.6 w t \% \mathrm{La}_{2} \mathrm{O}_{3}$, (f) $0.6 w t \% \mathrm{CeO}_{2}$ 


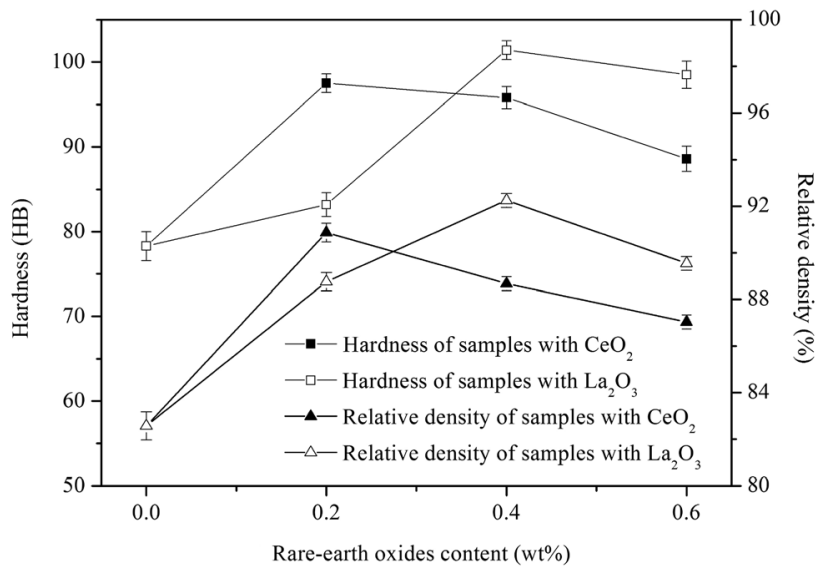

Fig. 8 Hardness and relative density of Fe-based friction material with different rare earth.

deformation and releases of the oxide film from the powder surface..$^{18}$ As shown in Fig. 6, the proper addition of rare-earth oxides contributes to refine iron particles significantly. Particles with small size is of high surface activity, which promotes the volume diffusion and surface diffusion of powders during sintering process. With the increase of temperature, the diffusion process becomes significant, which is helpful to the early formation of sintering neck. When the sintering process reaches to the holding stage, there are many vacancies at the edge of sintering neck, which reduces the curvature radius of grain boundary, and then spheroidizes pores. The smaller size of the powder, the more grain boundaries exist in the sintered body, and the vacancies at the sintering edge will diffuse to the grain boundaries and disappear, which makes the distance between particles shorter and more obvious, thus improving the densification of the material.

However, with further increases in the amount of rare-earth oxides, the powder's surface energy is increased sharply and the particles agglomerate. Thus, a small amount of rare-earth oxides $\left(0.2 \mathrm{wt} \% \mathrm{La}_{2} \mathrm{O}_{3}\right.$ or $\left.0.4 \mathrm{wt} \% \mathrm{CeO}_{2}\right)$ improved the density of sintered samples, while excessive rare-earth oxides destroyed the continuity of the structure.

Compared with the sintered sample with $0.2 \mathrm{wt} \% \mathrm{La}_{2} \mathrm{O}_{3}$, $0.4 \mathrm{wt} \% \mathrm{CeO}_{2}$ has better effect on the sintering densification of Fe-based friction material. It can be explained that the particle size of powder system with $0.4 \mathrm{wt} \% \mathrm{CeO}_{2}$ is finer than that of $0.2 \mathrm{wt} \% \mathrm{La}_{2} \mathrm{O}_{3}$, which increases the surface energy on the powder surface and promotes sintering densification. ${ }^{25}$

\subsection{Effects of rare-earth oxides on the properties of Fe-based friction materials}

Fig. 8 shows the relative density and hardness of sintered samples with different amounts of rare-earth oxides. When the content of $\mathrm{La}_{2} \mathrm{O}_{3}$ or $\mathrm{CeO}_{2}$ is increased, the relative density of sintered samples increases at first and then it decreases, with the maximum relative density of $90.87 \%$ and $92.25 \%$ occurring with $0.2 \mathrm{wt} \% \mathrm{La}_{2} \mathrm{O}_{3}$ or $0.4 \mathrm{wt} \% \mathrm{CeO}_{2}$.

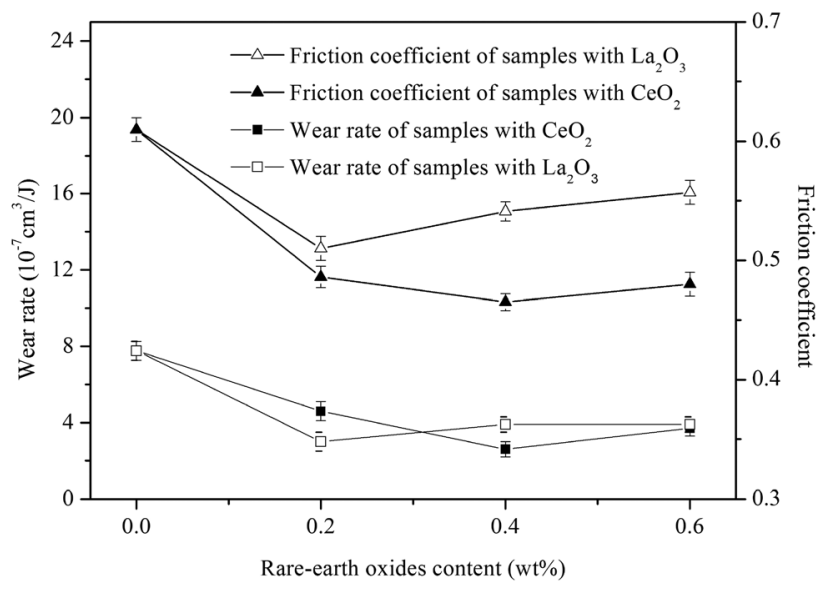

Fig. 9 Wear rate and friction coefficient of Fe-based friction material with different rare earth addition.

The hardness variation of sintered samples parallels that of the relative density variation. When $0.2 \% \mathrm{wt} \% \mathrm{La}_{2} \mathrm{O}_{3}$ or $0.4 \mathrm{wt} \%$ $\mathrm{CeO}_{2}$ is added, the hardness of the sintered samples reach the maximum values of 97.5 HB and 101.4 HB. An observation that is attributed to the higher relative density and uniform distribution of hard particles. The increased relative density can increase the effective area of bearing force and the uniformly distributed TiC particles contribute to hinder the movement of dislocations. ${ }^{26}$

However, when the addition of rare-earth oxides increases further, increasing number of irregular pores and agglomerated TiC appear in the microstructure. The stress concentration around pores and less effective area to bear external force will bring about the decreasing value of hardness.

The hardness improvement of $\mathrm{CeO}_{2}$ is better than that of $\mathrm{La}_{2} \mathrm{O}_{3}$ due to the different lattices. $\mathrm{CeO}_{2}$ has cubic lattice structure, the spacing between atoms is close to that of austenite atoms, and the mismatch between them is small, so $\mathrm{CeO}_{2}$ can be used to inhibit nucleation and strengthen fine grains. ${ }^{27}$ However, the hexagonal structure of $\mathrm{La}_{2} \mathrm{O}_{3}$ has a poor effect on grain refinement of austenite.

Fig. 9 shows the wear rate and friction coefficient of Fe-based friction materials with different rare earth contents. The friction coefficient and wear rate of sintered samples without rare-earth oxides were $7.8 \times 10^{-7} \mathrm{~cm}^{3} \mathrm{~J}^{-1}$ and 0.61 , respectively. With the addition of $0.2 \mathrm{wt} \%$ rare-earth oxides, the friction coefficient and wear rate of sintered samples were noticeably reduced. When the $\mathrm{La}_{2} \mathrm{O}_{3}$ exceeds $0.2 \mathrm{wt} \%$, the friction coefficient and wear rate of sintered samples increase slowly. When the $\mathrm{CeO}_{2}$ exceeds $0.2 \mathrm{wt} \%$, the friction coefficient and wear amount of the sintered samples decrease slowly at first, reaching the lowest value at $0.4 \mathrm{wt} \%$, and then increase slowly. In addition, $\mathrm{CeO}_{2}$ reduces the friction coefficient of sintered samples more obviously, but the two rare-earth oxides show little difference in their reduction of the wear rate of sintered samples.

The morphologies of the worn surface after test and the debris produced during the test are shown in Fig. 10. Obvious differences in worn surface and wear debris are observed as 

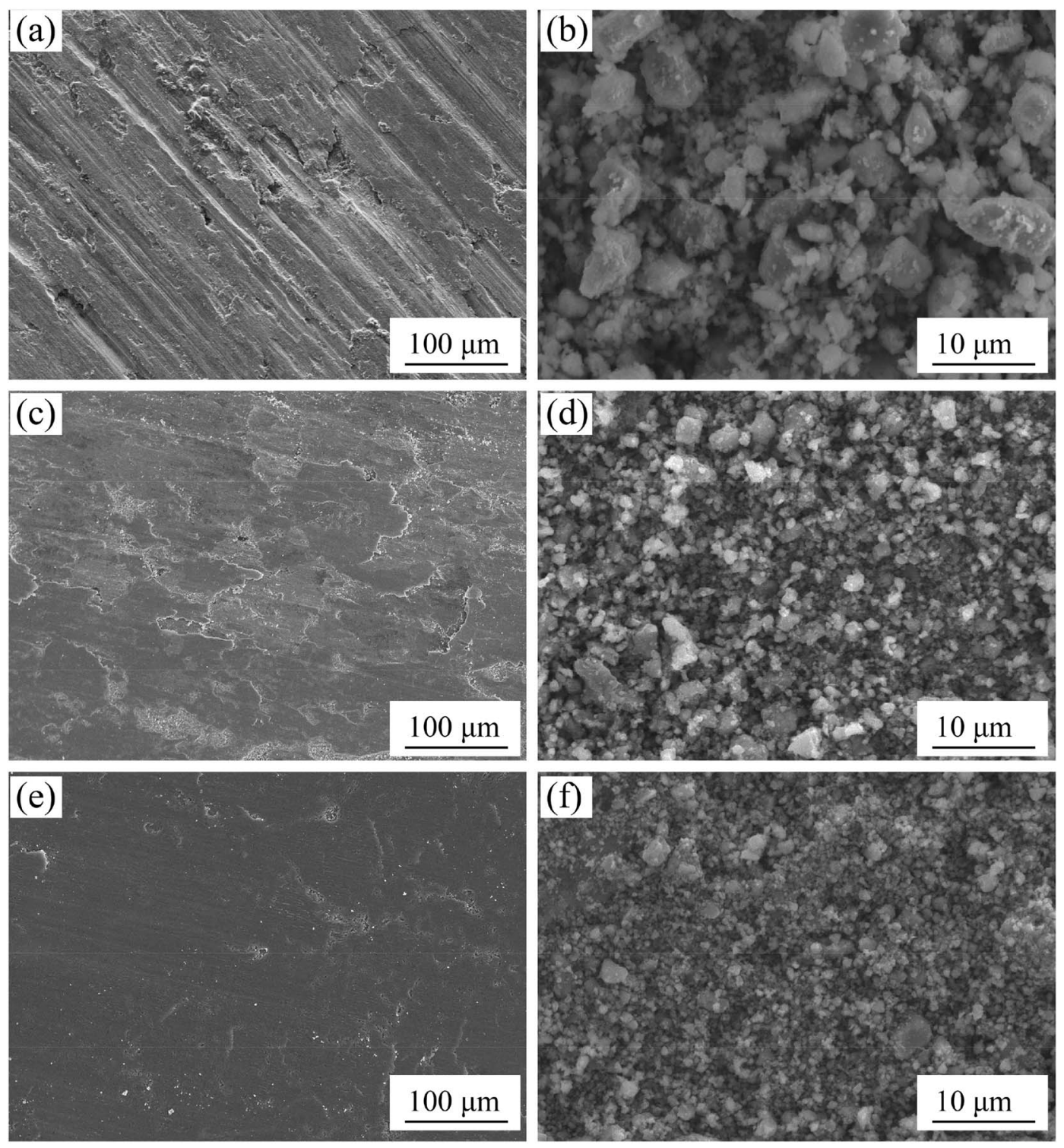

Fig. 10 Worn surface and wear debris of sintered samples. (a) and (b) without rare-earth oxide, (c) (d) La-0.2 wt\%, and (e) and (f) Ce-0.4.

a function of rare-earth oxides. The surface roughness and the degree of deformation decrease with $0.2 \mathrm{wt} \% \mathrm{La}_{2} \mathrm{O}_{3}$ or $0.4 \mathrm{wt} \% \mathrm{CeO}_{2}$. As shown in Fig. 10(a), grooves along the sliding direction and delamination fracture are seen on the surface of the sintered samples without rare-earth oxides. Compared with the wear debris of sintered samples with $0.2 \mathrm{wt} \% \mathrm{La}_{2} \mathrm{O}_{3}$ or $0.4 \mathrm{wt} \% \mathrm{CeO}_{2}$, the wear debris of sintered samples without rare-earth oxides is the biggest, around 7-8 $\mu \mathrm{m}$, as seen in Fig. 10(b).

When the addition of $\mathrm{La}_{2} \mathrm{O}_{3}$ increases to $0.2 \mathrm{wt} \%$ or the addition of $\mathrm{CeO}_{2}$ rises to $0.4 \mathrm{wt} \%$, grooves disappear the worn surface becomes smooth. There are a large area of lamellar exfoliations and wear debris (around $2-3 \mu \mathrm{m}$ ) on the worn surface of sintered sample with $0.2 \mathrm{wt} \% \mathrm{La}_{2} \mathrm{O}_{3}$ while only a small amount of oxide exfoliation and tiny wear debris (around $1 \mu \mathrm{m}$ ) appear on the worn surface of sintered sample with 0.4 wt $\% \mathrm{CeO}_{2}$.
In order to compare the elements variation of chemical states after sliding, the XPS results on Fe and C elements are analyzed in detail (shown in Fig. 11) and type of the metal oxides is listed in Table 5 .

In the presence of all the samples, the C1s peak can be fitted with the peak with binding energies of $284.8 \mathrm{eV}$, suggesting that graphite exists on the worn surface. ${ }^{28}$ It proves that there is graphite lubricating film on the worn surface. As for Re-0, the $\mathrm{Fe}_{2 \mathrm{p} 3 / 2}$ peak can be divided into two sub-peaks with binding energies of 709.4 and $711.4 \mathrm{eV}$, indicating the co-existence of $\mathrm{FeO}$ and $\mathrm{Fe}_{2} \mathrm{O}_{3}{ }^{29,30}$ When the addition of $\mathrm{La}_{2} \mathrm{O}_{3}$ increases up to $0.2 \mathrm{wt} \%$, the $\mathrm{Fe}_{2 \mathrm{p} 3 / 2}$ peak is divided into three sub-peaks with binding energies of $709.4 \mathrm{eV}, 711.2 \mathrm{eV}$ and $709 \mathrm{eV}$, indicating the co-existence of $\mathrm{FeO}, \mathrm{Fe}_{2} \mathrm{O}_{3}$ and $\mathrm{Fe}_{3} \mathrm{O}_{4} \cdot{ }^{31,32}$ When the addition of $\mathrm{CeO}_{2}$ is $0.4 \mathrm{wt} \%$, Fe element coexisting on the worn surface is in the form of $\mathrm{Fe}_{3} \mathrm{O}_{4}$ and $\mathrm{Fe}_{2} \mathrm{O}_{3}$, besides, the content of $\mathrm{Fe}_{3} \mathrm{O}_{4}$ is more than that of $\mathrm{Fe}_{2} \mathrm{O}_{3}$. 

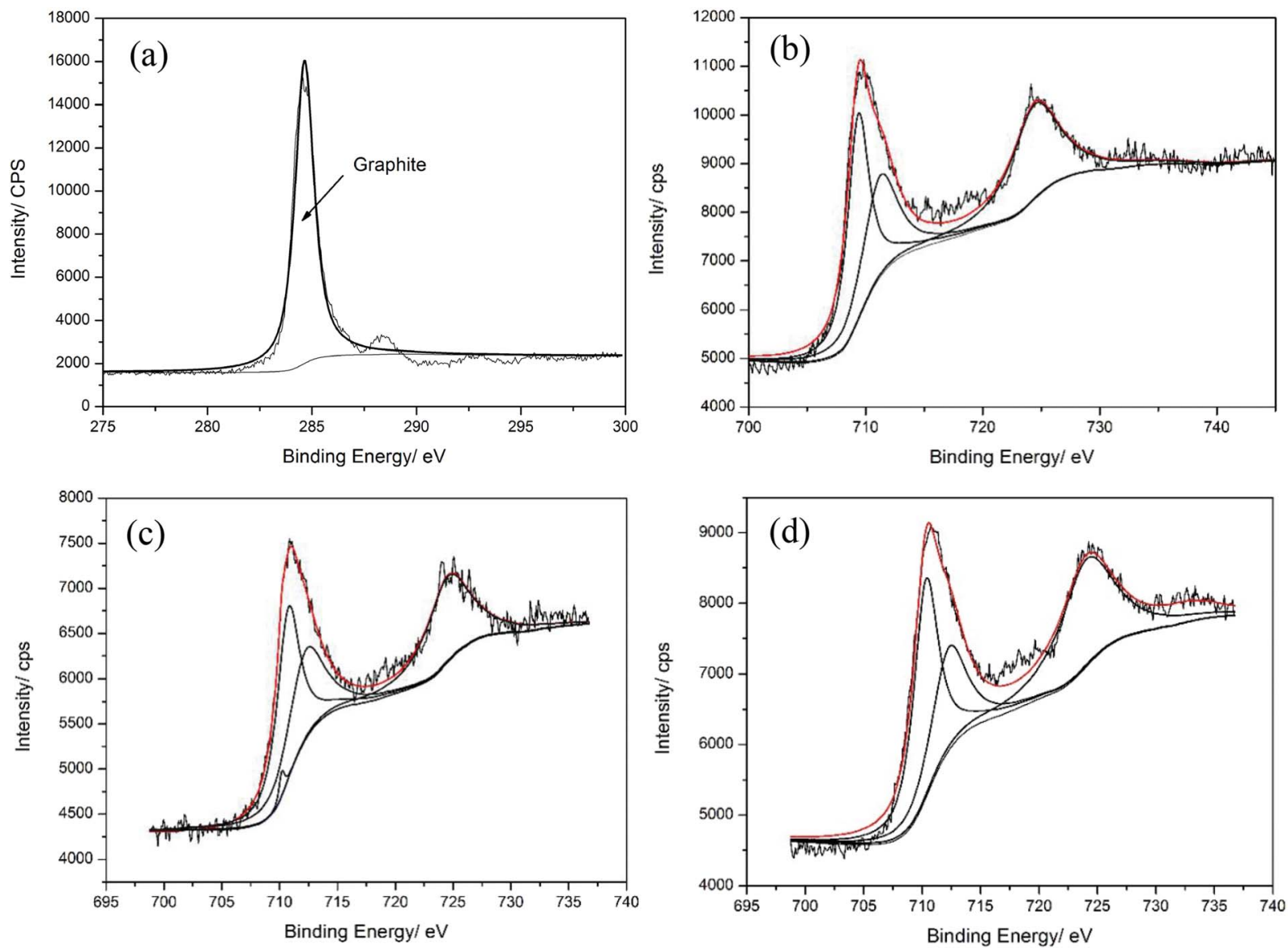

Fig. 11 XPS spectrum of the worn surface of sintered sample with different rare-earth addition: (a) carbon, (b) Fe on the worn surface of Re-0, (c) Fe on the worn surface of La-0.2, (d) Fe on the worn surface of Ce-0.4.

The tribological properties of Fe-based friction materials are closely related to the composition of oxide film, relative density and hardness. In the friction process, the oxide film is formed and thicken on the worn surface with increasing friction heat. As for the sintered sample without rare-earth oxides, the oxide film of that is consisted of $\mathrm{FeO}$ and $\mathrm{Fe}_{2} \mathrm{O}_{3}$. Tsuji and Hurricks have pointed out that when the oxide layer is mainly composed of $\mathrm{FeO}$, the wear rate of the material increases owing to the loose structure of $\mathrm{FeO}$ and the poor bonding strength with Fe matrix. ${ }^{33}$ Thus, the oxide film composed of $\mathrm{FeO}$ is prone to exfoliate and form large debris. Besides, the falling oxide particles and reinforced phase leave wide and deep furrows on the worn surface of the soft substrate owing to its low value of hardness, which increases the wear rate and friction coefficient of the material. Additionally, there are a large number of banded pores

Table 5 Oxides on the worn surface of Fe-based friction material

\begin{tabular}{ll}
\hline Sintered samples & The oxide of Fe \\
\hline Mo-0 & ${\mathrm{FeO}, \mathrm{Fe}_{2} \mathrm{O}_{3}}_{\text {Mo-1 }}{\mathrm{FeO}, \mathrm{Fe}_{2} \mathrm{O}_{3}, \mathrm{Fe}_{3} \mathrm{O}_{4}}_{\text {Mo-3 }} \mathrm{Fe}_{3} \mathrm{O}_{4}, \mathrm{Fe}_{2} \mathrm{O}_{3}$
\end{tabular}

in the Fe-based friction material without rare-earth. In the friction process, the sharp edge of the pore is easy to form stress concentration source and crack, which causes the tearing of particles and forms larger irregular particles. In a nutshell, it can be inferred that the wear type of Fe-based friction material without rare-earth are primarily severe oxidative wear and abrasive wear.

When $\mathrm{La}_{2} \mathrm{O}_{3}$ addition increases to $0.2 \mathrm{wt} \%$, the oxide film on the worn surface is consisted of $\mathrm{FeO}, \mathrm{Fe}_{2} \mathrm{O}_{3}$ and $\mathrm{Fe}_{3} \mathrm{O}_{4}$ while the oxide film on the worn surface of sintered sample with $0.4 \mathrm{wt} \% \mathrm{CeO}_{2}$ is composed of $\mathrm{Fe}_{2} \mathrm{O}_{3}$ and $\mathrm{Fe}_{3} \mathrm{O}_{4}$. Li DongSheng has pointed that $\mathrm{Fe}_{3} \mathrm{O}_{4}$ with spinel structure which is similar to graphite has excellent lubricating effect on the worn surface, which decrease the friction coefficient and wear rate obviously. ${ }^{34}$ Shin Jong-Han has pointed that the micro-hardness of $\mathrm{Fe}_{2} \mathrm{O}_{3}$ is up to $1000 \mathrm{HV},{ }^{35}$ which can be considered as the high-quality oxide film to resist plastic deformation during the friction process. Consequently, $\mathrm{Fe}_{3} \mathrm{O}_{4}$ and $\mathrm{Fe}_{2} \mathrm{O}_{3}$ binded well to $\mathrm{Fe}$ matrix keep the oxide films protect the worn surface from being ploughed by the hard abrasive particles, resulting in smooth surface. ${ }^{36}$ Besides, as the relative density and hardness of material increase, the number of pores decreases and the shape of them turns to be spherical. Therefore, the stress 
concentration source in the material decreases and the bearing capacity of the matrix to the oxide film increases. The falling debris repeatedly deforms on the worn surface, resulting in the change of debris shape. Comprehensively, the wear type of material with $0.2 \mathrm{wt} \% \mathrm{La}_{2} \mathrm{O}_{3}$ or $0.4 \mathrm{wt} \%$ $\mathrm{CeO}_{2}$ is mild oxidative wear.

In comparison of the sintered sample with $0.2 \mathrm{wt} \% \mathrm{La}_{2} \mathrm{O}_{3}$ or $0.4 \mathrm{wt} \% \mathrm{CeO}_{2}$, the tribological properties of the latter is better than the former. This is thought to be caused by three reasons. The first is the relative density of the latter is higher than that of the former, resulting in the less stress concentration sources and better supporting ability to oxide film. The second is $0.4 \mathrm{wt} \% \mathrm{CeO}_{2}$ contributes to the improvement of hardness more significantly compared with the sintered sample with $0.2 \mathrm{wt} \%$ $\mathrm{La}_{2} \mathrm{O}_{3}$ and the increase of hardness can improve the wear resistance of the material. The third reason is that the increased amount of $\mathrm{Fe}_{3} \mathrm{O}_{4}$ formed lubricating film improve the wear condition of the material.

\section{Conclusions}

In this study, in order to improve the tribological properties and service life of Fe-based friction material, effects of rare earth additions on the microstructures and properties of Fe-based friction material synthesized by in situ carbothermic reaction from vanadium-bearing titanomagnetite concentrates, are discussed in detail.

Additions of rare-earth oxides ( $\leq 0.6 \mathrm{wt} \%)$ contribute to the sintering densification process and the improved properties significantly. In particular, the friction coefficient decreases from 0.61 to $0.48-0.56$ and the wear rate reduces from $7.8 \times$ $10^{-7} \mathrm{~cm}^{3} \mathrm{~J}^{-1}$ to $2.6 \times 10^{-7} \sim 4.9 \times 10^{-7} \mathrm{~cm}^{3} \mathrm{~J}^{-1}$.

When the addition of $\mathrm{La}_{2} \mathrm{O}_{3}$ increases to $0.2 \mathrm{wt} \%$ or the content of $\mathrm{CeO}_{2}$ rises to $0.4 \mathrm{wt} \%$, the size of powder particles is reduced, resulting in the enhanced sintering densification. Comparatively, the relative density and hardness increase rapidly. Moreover, tribological properties are improved significantly. The wear rate decreases from $7.8 \times 10^{-7} \mathrm{~cm}^{3} \mathrm{~J}^{-1}$ to $2.6 \times$ $10^{-7} \mathrm{~cm}^{3} \mathrm{~J}^{-1}$ and the friction coefficient reduces from 0.61 to 0.48. The dominant wear type changes from severe oxidative wear and abrasive wear to mild oxidative wear. However, when $\mathrm{La}_{2} \mathrm{O}_{3}$ or $\mathrm{CeO}_{2}$ addition exceeds $0.2 \mathrm{wt} \%$ and $0.4 \mathrm{wt} \%$, powders accumulate and destroyed the continuity of the structure, as a result, the relative density and hardness are reduced. Furthermore, the wear rate and friction coefficient both increase.

The preparation of iron-based friction from vanadiumbearing titanomagnetite concentrates not only eliminate an enormous waste of precious resources during the conventional ironmaking process of the vanadium-bearing titanomagnetite concentrates, but also make full use of various elements in the vanadium-bearing titanomagnetite concentrates simultaneously to produce the iron-based friction material. This work can contribute to the improved tribological properties of Febased friction material significantly by adding rare earth oxides, which improves the service life of Fe-based friction material and expand the application field of this material.

\section{Conflicts of interest}

The authors declare that they have no conflict of interest.

\section{Acknowledgements}

This research is financially supported by the Science and Technology Plan of Panzhihua City in Sichuan Province of China under Grant No. 2017CY-C-1.

\section{References}

1 C. F. Xu, G. W. Dai, J. G. Han, et al., Investigation of Ni/ $\beta$-SiC on the friction and wear properties of dry copper-based powder metallurgy friction material, Powder Metall. Ind., 2016, 26(2), 1-7.

2 M. Yang. Effect of Al and Zr on Microstructure and Properties of $\mathrm{Fe}-18 \mathrm{Cu}$ Based Powder Metallurgical Friction Materials. Nanjing University of Aeronautics and Astronautics, 2011.

3 Y. Ma, Y. Liu, W. Shang, et al., Tribological and mechanical properties of pine needle fiber reinforced friction composites under dry sliding conditions, RSC Adv., 2014, 4, 36777-36783.

4 V. Merie, V. Candea, C. Birleanu, et al., The influence of titanium dioxide on the tribological characteristics of a Febased friction composite material, J. Compos. Mater., 2014, 48(2), 235-243.

5 T. Peng, Q. Z. Yan and Y. Zhang, Low-cost solid FeS lubricant as a possible alternative to $\mathrm{MoS}_{2}$ for producing Fe-based friction materials, Int. J. Miner., Metall. Mater., 2017, 24(1), 115-121.

6 C. Gachot, A. Rosenkranz, S. M. Hsu, et al., A critical assessment of surface texturing for friction and wear improvement, Wear, 2017, 372-373, 21-41.

7 M. H. Cho, J. Ju, S. J. Kim, et al., Tribological properties of solid lubricants (graphite, $\mathrm{Sb}_{2} \mathrm{~S}_{3}, \mathrm{MoS}_{2}$ ) for automotive brake friction materials, . Wear, 2006, 260(7-8), 855-860.

8 T. K. Bandyopadhyay, S. Chatterjee and K. Das, Synthesis and characterization of TiC-reinforced iron-based composites Part I on synthesis and microstructural characterization, $J$. Mater. Sci., 2004, 39(18), 5735-5742.

9 Z. Mei, Y. W. Yan and K. Cui, Effect of matrix composition on the microstructure of in situ synthesized TiC particulate reinforced iron-based composites, Mater. Lett., 2003, 57(21), 3175-3181.

10 A. K. Srivastava and K. Das, Microstructure and abrasive wear study of (Ti, W)C-reinforced high-manganese austenitic steel matrix composite, Mater. Lett., 2008, 62(24), 3947-3950.

11 G. M. Zhang, K. Q. Feng, Y. Li, et al., Effects of sintering process on preparing iron-based friction material directly from vanadium-bearing titanomagnetite concentrates, Mater. Des., 2015, 86, 616-620.

12 N. J. Welham and P. E. Willis, Formation of TiN/TiC-Fe composites from ilmenite $\left(\mathrm{FeTiO}_{3}\right)$ concentrate, Metall. Mater. Trans. B, 1998, 29(5), 1077-1083. 
13 R. Khoshhal, M. Soltanieh and M. A. Boutorabi, Formation mechanism and synthesis of $\mathrm{Fe}-\mathrm{TiC} / \mathrm{Al}_{2} \mathrm{O}_{3}$ composite by ilmenite, aluminum and graphite, Int. J. Refract. Met. Hard Mater., 2014, 45, 53-57.

14 G. M. Zhang and K. Q. Feng, Synthesis of iron-based friction material by in situ reactive sintering from vanadium-bearing titanomagnetite, Mater. Manuf. Processes, 2016, 31(2), 198205.

15 G. M. Zhang, K. Q. Feng and H. F. Yue, Theoretical analyses and experimental investigations of selective carbothermal reactions of vanadium-bearing titanomagnetite concentrates for preparation of iron-based wear-resistant material, JOM, 2016, 68(9), 2525-2532.

16 Y. Shui, K. Q. Feng, Y. Y. Zhang, et al., Influence of Mn on the iron-based friction material directly prepared by in situ carbothermic reaction from vanadium-bearing titanomagnetite concentrates, RSC Adv., 2018, 8(64), 36503-36511.

17 J. Y. Liu, Y. C. Liu, Y. S. Yin, et al., Effects of rare earth in ball milling of Fe-based high chromium alloy powder, J. Rare Earths, 2000, 18(4), 347-350.

18 B. N. Liang and Z. Y. Zhang, Development of P/M Fe-Ni-RE material containing rare-earth elements, New Technology \& New Process, 2004, 9, 52-53.

19 L. Wang, Z. Y. Zhang and P. P. Yao, The research of sintering pressure of Fe-based powder metallurgy brake materials, Lubr. Eng., 2008, 33(8), 10-13.

20 G. H. Zkan, M. Kemal Bilici, et al., Enhancing the wear properties of iron based powder metallurgy alloys by boron additions, Mater. Des., 2007, 28(7), 2255-2259.

21 C. X. Liang and Y. Pan, The effect of $S$ on the properties of powder metallurgy iron-bronze based bearing materials, Lubrication. Eng, 2010, 35(1), 62-66.

22 Y. Li, K. Q. Feng, W. L. Deng, et al., Influence of RE Addition on Ferro-Matrix Friction Material by In Situ Carbothermal Reduction from Vanadium-Bearing Titanomagnetite, Adv. Mater. Res., 2014, 936, 1262-1266.

23 Department of Metals, Sun Yat-sen University, Physicochemical Constants of Rare Earths, Metallurgical Industry Press, Beijing, 1978.
24 D. William and J. R. Callister. Fundamentals of Materials Science and Engineering, Chemical Press, Beijing, 2004.

$25 \mathrm{H}$. Zhang. The study on mechanism of rare earth elements in iron-based powder metallurgical friction material, China Academy of Railway Sciences, 2003.

26 Y. Shui, K. Q. Feng, Y. Y. Zhang, et al., Effect of Ni content on iron-based friction material prepared by in situ synthesized from vanadium-bearing titanomagnetite concentrates, $J$. Mater. Eng., 2018, 46(9), 73-79.

27 Y. Wang, J. J. Liu and Z. H. Yu, Effect of rare earth elements on microstructure and wear resistance of laser remelted iron alloy coatings containing metalloids, Surf. Eng., 2013, 9(2), 151-155.

28 B. J. Bachman and M. J. Vasile, Ion bombardment of polyimide films, J. Vac. Sci. Technol., A, 1989, 7(4), 27092716.

29 N. S. Mcintyre and D. G. Zetaruk, X-ray photoelectron spectroscopic studies of iron oxides, Anal. Chem., 1977, 49(11), 1521-1529.

30 G. C. Allen, M. T. Curtis, A. J. Hooper, et al., X-Ray photoelectron spectroscopy of iron-oxygen systems, $J$. Chem. Soc., Dalton Trans., 1974, (14), 1525-1530.

$31 \mathrm{M}$. Oku and K. Hirokawa, X-ray photoelectron spectroscopy of $\mathrm{Co}_{3} \mathrm{O}_{4}, \mathrm{Fe}_{3} \mathrm{O}_{4}, \mathrm{Mn}_{3} \mathrm{O}_{4}$, and related compounds, $J$. Electron Spectrosc. Relat. Phenom., 1976, 8(5), 475-481.

32 P. Mills and J. L. Sullivan, A study of the core level electrons in iron and its 3 oxides by means of X-ray photoelectronspectroscopy, J. Phys. D: Appl. Phys., 2000, 16(5), 723.

$33 \mathrm{~W}$. Hirst and J. K. Lancaster, The Influence of oxide and lubricant films on the friction and surface damage of metals, Proc. R. Soc. A, 1954, 223(1154), 324-338.

34 D. S. Li, X. F. Wang, Z. G. Zhong, et al., Study of the tribological characteristics of aircraft friction material, $J$. Mater. Eng., 1997, (3), 3-6.

35 J. H. Shin, D. S. Lim and H. S. Ahn, Effect of annealing and $\mathrm{Fe}_{2} \mathrm{O}_{3}$ addition on the high temperature tribological behavior of the plasma sprayed yttria-stabilized zirconia coating, Surf. Coat. Technol., 2000, 133(11), 403-410.

36 S. Q. Wang, M. X. Wei and Y. T. Zhao, Effects of the tribooxide and matrix on dry sliding wear characteristics and mechanisms of a cast steel, Wear, 2010, 269(5), 424-434. 